\title{
Forming a Medical Work-Object
}

The Case of General Medicine and Obstetrics

\section{Anne-Chantal Hardy}

Translator. Gabrielle Varro

\section{(2) OpenEdition}

\section{Journals}

\section{Electronic version}

URL: http://journals.openedition.org/travailemploi/7634

DOI: 10.4000/travailemploi.7634

ISSN: $1775-416 \mathrm{X}$

\section{Publisher}

DARES - Ministère du Travail

\section{Printed version}

Date of publication: 30 December 2017

Number of pages: 77-102

ISSN: 0224-4365

\section{Electronic reference}

Anne-Chantal Hardy, "Forming a Medical Work-Object", Travail et Emploi [Online], Hors-série | 2017.

Online since 11 July 2019, connection on 12 April 2021. URL: http://journals.openedition.org/

travailemploi/7634 ; DOI: https://doi.org/10.4000/travailemploi.7634 


\title{
Forming a Medical Work-Object
}

\section{The Case of General Medicine and Obstetrics*}

\author{
Anne-Chantal Hardy**
}

\begin{abstract}
A work-object can be defined as what makes sense of an activity, i.e. that gives it both meaning and direction. In contexts where all doctors are specialists and perform very different tasks, is it possible to find a work-object that might be shared by the entire medical profession? After challenging the concept of "work-object" and the various ways it can be analysed, the author attempts to grasp its most widespread characteristic, i.e. what doctors are taught during the first six years of medical school. She then goes on to dissect two medical specialties -general medicine and obstetrics and gynaecology (O\&G)- and shows that a work-object, practically inseparable from the way it is taught, evolves differently in each discipline. This leads to discussing the link between practical and theoretical training, that could apply to all healthcare activity, and even beyond, to other professions.
\end{abstract}

\footnotetext{
Al of us have, tucked away in the back of our minds, at least one unforgettable Ascene -Charcot presenting a hysterical woman to his colleagues, ${ }^{1}$ an operation or dissection being carried out in the middle of an amphitheatre- because medical training is always a matter of showing and seeing. When the day comes that, ourselves in hospital, we must face the pack of students crowding into our room behind "the professor", we realize that may be what "learning by the sickbed" means.

What in fact does the expression: "by the sickbed" imply? It is true that doctors learn next to hospital beds but do they really learn from the patient? Is it the patient who provides the substance to be learnt or is that made of something else? What are students being taught to see when they are "shown" a patient?

* Translation: Gabrielle Varro.

Article published in French in Travail et Emploi, no 141, janvier-mars 2015.

** Droit et changement social (The Law and Social Change, Research Lab UMR 6297) affiliated to the CNRS and Nantes University; anne-chantal.hardy@univ-nantes.fr.

1. What springs to mind here, for instance, is the famous painting by André Brouillet showing Professor Charcot teaching hysteria at the Salpêtrière Hospital towards the end of the 19th century.
} 
For Eliot FREIDSON (1970, p. 172), observing medical practice in American postwar clinics, it went without saying that a doctor's job was above all else practical: "It is by nature not very theoretical, rather it is applied work, and thereby clearly differs from what a researcher does." That remark calls for two comments.

In the first place, the American sociologist was observing a mainly consulting form of practice, at a time when medicine was chiefly clinical. As Michel FouCAult (1963, p. XIV) explained, clinical thinking is primarily pragmatic, due to the "infinitesimal but decisive change that replaced the question 'what's the matter?' with that other question which, in the 18th century, inaugurated the dialogue between doctor and patient $[\ldots]$-and by which we acknowledge the basic tenets of the clinical approach'Where does it hurt?'” The question implies that it is through the suffering expressed by the patient that a disease takes shape. What we are actually seeing is a practitioner responding to a demand, most often expressed in terms of pain; he/she must try to "solve the person's real problems" (FrEIDSON, op. cit.). But FoucAult well knew that the real issue was on the contrary a certain way of producing a personal discourse on the disease, revealed by the "symptom" (the signifier). Clinical empiricism could during the 1950s produce positive effects, but the arrival of forward-looking medical practice, that permits a disease to emerge by circumventing all symptoms, forces us to reconsider our reading of FREIDSON.

This necessarily means separating work from the work-object. Work is what in fact is taking place, the work-object what gives it meaning. We may therefore hypothesize that if a doctor's (especially a clinician's) job consists in responding to a patient's demands, what guides them is nevertheless of a different nature. The doctor's problem is doubtless different from the patient's.

To be more precise, the concept of "work-object" forces the sociologist to try and break away from the strong preconceptions that prevail in the domain, to reinterrogate medical practice in concrete terms, from the standpoint of what gives it meaning. Everyone has an idea of what medical work consists in, if only because we have all been submitted to it at one time or another. The issue therefore deserves to be dealt with by finding the conceptual and methodological tools allowing the sociologistand-erstwhile-patient to establish a healthy distance between him/herself and his/her observations, and above all between him/herself and his/her interpretations.

Though it takes place in university, a doctor's training is largely made up of periods of practical internships. And though it is difficult to determine the exact proportion of theory and practice involved in the curriculum -since medical schools are all organised differently and depending on the specialty involved-we may nevertheless consider that they represent approximately equivalent amounts. Professor Robert Debré's plan to turn hospitals into places where newly qualified doctors would receive a real, practical education was at the very core of the reform of medical studies in France in 1958 (JAMOUS, 1969). 
The preconception that training is above all else practical is echoed by the practitioners themselves, who often claim that they only truly learnt their trade during the third cycle of studies, when, becoming interns in residence, they received very little theoretical training and were already considered professionals. As Howard BECKER and his colleagues put it (2005 [1st ed. 1961]), a student only really learns to be a student, and a trade can only be learnt by doing. And since doctors seem to be formed by interacting with their patients, one might imagine that the object of their training -and thus of their work- is simply the patient. The sick person could then represent the work-object shared by the entire health profession. ${ }^{2}$ But that is merely an appearance, the smokescreen that we are here proposing to dispel, to see how the medical work-object forms.

We will be calling upon four sets of combined and synthesized data. The first is made up of studies bearing on the professions, on professional groups and on how the concept of "profession" (beyond medicine) developed. The second set of data emerges from surveys we carried out at different times since the early 1990s, mainly but not exclusively within the medical profession. ${ }^{3}$ The third is a more informal ensemble that arose gradually over time, as I followed up and participated in medical training programmes, in collaboration with university departments of general medicine, to see how they evolve, by attending hospital residents' conferences, and by analysing the academic and professional literature. The fourth and last set of data was gathered while observing healthcare professionals on the job in an obstetrics ward, ${ }^{4}$ as part of ongoing research on maternal and perinatal healthcare, and the sorts of professional team-work produced, some part-results of which will be presented here.

We shall first focus on the concept of work-object and the various ways it can be questioned. Defined first as a process, it can be particularly well scrutinized at given moments, for instance when recruiting personnel or during training periods. We will next tackle two examples of professional specialties -general medicine and obstetrics and gynaecology $(\mathrm{O} \& \mathrm{G})$ - to see how the work-objects develop in these two medical fields. This will lead us to analysing how theory and practice pull together in the broader arena of the health professions more generally.

2. Some might think the answer lies somewhere between object and subject, and besides, it is precisely to combat the denial of the sick subject that some doctors try to defend a more subjective form of medicine (DuBAS, 2004). That opposition is not what we are dealing with here, however; we are considering the object not in its relation to the person but in its relation to work. The concept of object, here, is not a concrete, but rather a practical notion: stating that there is no work without an object is therefore not saying that the subject has been "objectivated" in the sense of seen as an object, but that work bears on (and is borne by) one (or several) objects that make it meaningful.

3. The first joint research projects, bearing on the effects of the reform of the medical residency (internat de médecine) in 1982, came out at the start of the years 2000, followed by other research on medical curricula (GADÉA, HARDYDUBERNET et al., 2005) and on students' choices at the end of the national medical examinations (HARDY-DUBERNET, FAURE, 2006.). More recently, a series of direct observations was carried out in the obstetrics ward of a University hospital (CHU), completing research carried out in collaboration with the Midwifery School in Nantes.

4. Aside from the professional midwives in charge, other midwives and doctors (obstetrician-gynaecologists and aenesthesists), orderlies and child-care assistants, nurse anaesthesists and sometimes paediatricians all work together in the obstetrics ward, also called the "Delivery Room". 


\section{The Medical Work-Object Grasped at its Inception}

\section{Taking Off from the Work-Object}

Since Georges FRIEDMANN (1950), the sociology of work has paid much attention to workers on the job, describing their activities to understand how they manage their constraints to preserve a little of their self-sufficiency, how they build up their professionalism, what their collaborations are based on and on what they base their demands. The sociology of the professions in France today seems to be returning to on-the-job observations, particularly since the notion of professionalisation has been applied to an ever-broader range of occupations (DEMAZIÈRE, GADÉA, 2009; BOUSSARD et al., 2010). The distinction between "emblematic and accomplished" professions (DEMAZIÈRE, 2009, p. 84) -with doctors in the forefront- on the one hand, and, on the other, "professional groups" (CHAPOULIE, 1973) studied in the Chicago School tradition, throws the often rough and somewhat artificial categorisations that separate a "real" profession from a trade -whose "professionalisation" must nevertheless also be acknowledged- in perspective (Piotet, 2002; Demazière, 2008). The sociology of the professions, medical sociology in particular, has more often explored what is at stake within a professional group and its recompositions rather than the actual practice and exercise of the trade. ${ }^{5}$ In fact, professional autonomy is frequently presented as such an obvious feature of medical work, and scientific expertise as so difficult for a layman to understand that research bearing on medical practice rarely involves analysing the meaning of the acts themselves - which would also require that exchanges between patients and doctors be "retranslated" in order to deconstruct expert thinking, as Aaron V. Cicourel (2002) has attempted to do.

A work-object can be defined by the process that makes sense of a work activity (HARDY, 2013). Sense here covers both meaning and direction. The object is never predefined, whether by professionals, ${ }^{6}$ institutions or users. It is above all an operational concept and a methodological tool for inspecting a professional act under a particular angle, postulating that the researcher knows nothing about it. Such an attitude on the part of the researcher may at times spontaneously emerge when dealing with an unfamiliar occupation, but is much less common concerning activities with which we are all conversant. The work doctors do, for instance, seems fairly accessible and familiar, since we have already had dealings with them and the opportunity to see them "at work". Nonetheless, familiar professions appear the most heuristic when questioning a work-object, precisely because they permit dissecting the preconceptions that always more or less inhabit a sociologist. For how can we "objectively" study an

5. With a few exceptions, such as the research on surgeons by Jean PENEFF (1997) or by Nicolas DodIER (1993) on occupational health doctors.

6. Though one needs to comprehend how work becomes meaningful for the professionals themselves, as e.g. in Alexandra BIDET (2010) on the subject of "real work", the concept of work-object reaches beyond actors' self-evaluation and includes the processes of training -basic and life-long training-and of co-opting the members of their professional group. 
activity of which we are, have been, or will someday be the target? How can we avoid somehow fitting into the relationship between giver and receiver of care? Though it seems hardly possible, or even desirable to neutralise the observer's gaze, it has appeared worthwhile on several occasions to dispose of tools allowing one to direct the interpretation of the images obtained.

From a general point of view, any work-object can be investigated by asking relatively simple questions, such as: how are the professionals recruited? How are they assessed? What determines the quality of the work accomplished? When does an activity begin, when does it end? Training is a particularly favourable opportunity to observe how a work-object is formed, because, in order to be learnt and internalised by the professional, it must in one way or another be given visibility and expression. What is afforded value during the learning process is a clue as to what the object itself is made of. The sorts of both material and symbolic gratification are powerful indicators of the makeup of a work-object.

\section{What is a Medical Work-Object?}

The fact that working conditions in both general medical practice and specialties are so different could leave the impression that no work-object common to the entire medical profession can possibly exist. But it depends on how you look at it. Observing doctors on the job, biologists and generalists or surgeons and school doctors, for instance, seem to have very little in common. Yet, all of them received the same medical training for at least six years (Box 1), a fact that cannot be ignored, because that is precisely where the first object for all doctors takes shape. The work-object all doctors have in common must therefore be found within that six year period, and that is precisely where we went to look for it.

\section{Box 1}

\section{A Doctor's Training}

Doctors learn at university, in medical departments that function in specific ways. Though nearly all second-year students are science majors (LABARTHE, HERAULT, 2003), every high-school graduate is eligible to register in first year. Since 1972, accessing the second year of med school in France depends on a competitive exam, the quota being set by the Ministry of Health since 1983. The number of places available varies considerably: from over 12,000 the first year, the quota fell to 3,500 in the early 1990s, then rose again to more than 7,000 today. Since 2011, the first year is identical for all future General Practitioners (GPs), dentists, pharmacists and midwives, and, in some university departments, physiotherapists.

The BA-MA-PhD system (licence-master-doctorat - LMD) that all medical and other schools in France must conform to today, is not very well suited to medical studies, 
traditionally organised in three cycles. The first two-year cycle corresponds to basic training; the second (a four-year cycle), to semiology and therapeutics. Those first six years are validated by the universities but finalised by National Ranking Examinations (épreuves classantes nationales - ECN), which aim to give all medical students in France a rank according to which each will choose their branch and geographic location for the third cycle. Since 2004, these national examinations have replaced the specialty residents' competition (internat de spécialité). During the last three years of the second cycle, students are considered "hospital students" for they spend half their time in training and are paid hospital wages. This has replaced the status of "extern", a term however still currently used. The thesis in medicine is certified by a "practising doctor's" degree (doctorat d'exercice) but is not equivalent to a doctorate; in the LMD system, it is more like a Master's degree. Therefore, in order to obtain a position as faculty member, students must undertake a scientific Master's and a Doctorate, usually in the life sciences, less frequently in the humanities. French medical schools have recently introduced doctoral study programmes.

Within the scope of this paper, it is barely possible to broach all the details of the education that all doctors receive, and its consequences for the forming of a common work-object. What we can do, however, is synthesize a few of its main features by taking off from conceptual pairs that sometimes oppose without exactly contradicting each other, and which constitute the dialectical props of a sometimes paradoxical, common outlook. The main parameters of that education are: training/classifying; theory/practice; general/specialised. Each dyad reveals ways of combining, joining or opposing that, in fine, permit to better grasp how the common medical work-object is formed.

\section{Combining Training and Classifying}

Medical practitioners make up a regulated and until now extremely stable profession, as illustrated by the fact that there are very few individuals today who hold a medical degree but excercise a different profession; the correlation between a medical degree and employment is probably one of the strongest in existence, all health professions included. ${ }^{7}$ Consequently, all of those who access second year of med school are very likely to remain in the profession their entire life. That exceptional proximity between professional degree and position (BOURDIEU, BOLTANSKI, 1975) leads public authorities to make demographic forecasts whose outcomes -in a healthcare system

\footnotetext{
7. However, that stability and its evolution are difficult to assess, because the main surveys concerning professional integration exclude the medical university curricula, as if the question were resolved a priori (CALMAND, 2013). At the same time, data forthcoming from the French National Medical Council (Conseil de l'ordre des médecins) show that, on the one hand, newly qualified doctors take longer than their senior colleagues to open their own office, but also, on the other hand, that when they retire an increasing number of doctors no longer figure in the Order's directory. This last point would seem to indicate that they have migrated to other occupations but work done by the Department of Research, Studies, Evaluation, and Statistics (Direction de la recherche, des études, de l'évaluation et des statistiques - DREES) does not for the moment confirm it (BILLAUT, 2006).
} 
largely dependent on the private sector-are key. The competitive examination at the end of the first year is today common to four medical professions; to all intents and purposes it is tantamount to being recruited and has a strong impact on the structure of the professional group. At the end of the sixth year, another examination distributes the future doctors among the specialties. The ECN (épreuves classantes nationales National Ranking Examinations) are neither a competition (there are more positions than candidates) nor an ordinary test (the grade obtained is not punitive): its only aim is to place thousands of medical students each year in a pecking order and allocate them to the specialty residencies of university hospitals in France. The test therefore aims to appoint candidates to the various residencies across the country; it is akin to a vast, national employment plan to fill the various medical specialty positions by delving into the stock of medical students registered in sixth year of university, chosen and appointed to the positions still available in accordance with each individual's rank (HARDY-Dubernet, FAURe, 2006).

The two tests are exclusively theoretical, organised largely on the basis of systematically assessed knowledge, since the objective is mainly to classify. It is only once the ECN rankings are over that students are no longer under obligation to be classified and can actually concentrate on learning the specialty they chose by will or by force. They do hospital internships early on in their itinerary which are certified but not graded (and therefore do not enter into the ranking system). As a result, there is a confusion between the aim of education: everyone must share the same basic body of knowledge, and the aim of selection: establishing a hierarchy among the students. The first part of their medical education (the first six years) centres on learning the theory; the sick person's actual state of health remains in the background. Diseases are learnt through the so-called "fundamental" subject matters, and will be incarnated "for real" by the patients only later. That sort of apprenticeship obliges doctors to reshuffle their theoretical knowledge so that when the moment comes it may help them make a diagnosis or decide on a prescription. The predominance of classifying over practical logics is part of a system that organises candidates' performances in a hierarchy, the results of which translate into greater or lesser freedom of choice as to residency, i.e. their future specialisation. Put otherwise, the more brilliant a candidate, the greater their opportunities; the less well they performed in the competition, the less choice they will have for their future occupation. The powerful constraints that weigh on the students are equal to the considerable amount of freedom professionals demand. That logic, not unlike a meritocracy, also appears fundamentally "liberal", in the sense that pitting students against each other is supposed to improve the performances of the entire group and permit a "natural" regulation of healthcare. The system is largely disputed today, but for a long time it was at the root of the reform of medical studies in France. 


\section{Joining Theory and Practice}

Basically, the first six years of medical studies also structure a group fated to split up into various specialties. What keeps this professional community together is the way they were taught theory, which is an essential part of their assessment, whereas the first internships done in the field are for them more a source of information -they learn their place in a university hospital structure- than a source of practical knowledge: trainees remain relatively passive. ${ }^{8}$ The pedagogical organisation over the years bears witness to the fact that the object was built up the most abstractly possible through various disciplines (chemistry, biology, statistics, etc.) before zeroing in on the study of symptoms (semiology) and how to treat them. The "doctor's disease" emerges from biological phenomena even before any bodily manifestations; with relation to the patient and his/ her body, the "disease" pre-exists and can be studied without the patient expressing anything at all. The break with what each student may have pictured the medical field to be before entering medical school, on the one hand, with non-professional health workers suddenly transformed into "laypersons", on the other hand, is at the core of the mechanisms that shape the profession thanks to the gradual formation of a common object. From this standpoint, that break is truly a practical test, since it literally means that individuals are being displaced from one world to another.

At no time in the course of their education are theory and practice "on a par", because it begins with theorising and ends with practising. Their studies are structured by that sort of organisation, which positions what doctors learn along a scale of values. Doctors claim to have learnt their trade during their residency and "in the field", because that is where they are confronted with others and placed in bonafide social and professional relationships. The passage from suffering person to "patient" takes place at the same time as the shift from "layperson" (which they are when still only students) to doctor, but only after the theoretical object was created.

Theoretical knowledge is evaluated in the same manner for all the students and organised centrally by the responsible French ministries and the universities. It thus forms a bond that unites them all. Practice, on the other hand, and subsequently being appointed to a hospital or university position, are largely left to the subjective appreciation of their peers and to co-opting colleagues. ${ }^{9}$ Though today there are some departments where the quality of teaching is to a certain extent controlled, no practical evaluation is ever carried out in front of an outside teacher. ${ }^{10}$ Here again, professionals

\footnotetext{
8. Our research has revealed the different phases of a trainee's activity according to year. Nicknamed "corridor clots" ( «thrombus de couloir») during their first years, because they clutter up the wards without doing anything, they often teach themselves how to be useful. Learning that way also teaches them autonomy.

9. For instance, the possibility of entering upon a hospital career is left up to the Department Head, who decides who will be allowed to apply for a position in his/her ward. In the same way, teaching assistant positions and professorships are not open to competition; most often, there is only one applicant, pre-selected and for whom the post will be the "result" of a competitive examination.

10. That is the case in midwifery or nursing schools: their training period is evaluated and validated by the intern's referee in the ward, but the teachers also make the rounds of the internship locations to evaluate the students on the job.
} 
learn about value while acquiring the awareness of their autonomy, which is mainly the practical freedom to apply their own judgment.

From the very first day of their residency, the future practitioners are to all intents and purposes professionals, with the power to prescribe -a doctor's most symbolic act. Paradoxically, the residents who rank highest, the most "brilliant", are often those who up to that point placed theoretical above practical learning, to such an extent that beginning work as a practitioner becomes problematic. So much have the "patients", by becoming real -with their fuzzy symptoms, uncontrollable complaints and all-too present relatives- disrupted the study and treatment of the "disease", that theory becomes their refuge and research their salvation. ${ }^{11}$

It is not the patient, in any case, who served to develop the work-object and it is not by their ability to "listen" that young doctors can justify their practice. At the start of their residency, the disease has not yet been embodied: it is the subject of a theoretical exam, a sum of abstract notions.

The joining of theory and practice reveals the particulars of an education which, though attributing an important place to practical training periods, is above all organised round a mainly abstract focus - which makes one wonder about the nature of what health professionals learn on the job, according to where the various phases of teaching are placed on the overall syllabus.

\section{Opposing General and Specialised}

Traditionally, and until the early 1980s, medicine was "general". One might even say, as Michel ARLIAUd (1987, p. 92) put it, that "for the main part, there was no institutionally established hiatus in the professional field." Even though professional hierarchies cropped up internally, one could always refer to an "official medicine, that was above all general and liberal" (loc. cit.). Until 1983, all doctors were primarily GPs, general medicine being what was taught during the first six years of medical school, specialties coming only later. Most doctors, including residents, have done substitute work as GPs during their studies, trying themselves out on the job. Some found it interesting, others preferred to specialise, usually remarking that being that sort of doctor was much more complicated than caring for a single bodily function or organ.

The notion of medical specialty is particularly complex, harking back to various logics that, when implemented, translate into sometimes contradictory mechanisms. Depending on the point of view, there are therefore various ways of approaching it.

One approach, following the work of interactionist sociologists, particularly Everett C. Hughes (1996) and Anselm L. STRAuss (1961; 1992), consists in viewing specialisation as the result of a segmentation of the professional body. Studying hospital

\footnotetext{
11. Some young doctors we met promoted the idea that a "patientless" medical practice was much more effective because freed from the slag of human interactions, since all the data (blood tests, x-rays, etc.) can be accessed on an electronic file.
} 
work, these authors noted a division of labour that led to the creation of segments whose contours had to be constantly redefined. Professionalisation as a process is considered the accretion of segments pursuing different aims, more or less subtly maintained under a common name at a specific time in history (STRAUSS, 1961; 1992, p. 69). That process takes on different forms, however, depending on the country; specialising does not happen in the same way in France, Great-Brittan or Germany (WEISZ, 2006).

Specialisation can also be imagined as the result of institutional adjustments and negotiations. In France, the move towards specialisation was due to the overlapping of several processes, in particular those linked to the training system and public authorities resolved to control the exercise of specialties by law, via Social Security (PINELL, 2004). Though today there is a near-perfect harmony between third cycle studies, specialty degrees and the specialties acknowledged by the Social Security system, that has not always been the case. For a long time, parallel and sometimes discordant ways of acknowledging a specialty coexisted: the French National Medical Council could recognise a physician's qualification. Lastly, the logics underlying specialisation do not correspond to a single mode of division of medical labour. Certain specialties are "populational" (women, children, seniors, workers, etc.), others concern an organ (skin, eyes, etc.), a system (digestive, cardiovascular, musculoskeletal, etc.) or a function (endocrinology, hematology, etc.); other specialties refer to specific techniques or therapies (surgery) or diagnoses (radiology, biology); lastly, some concentrate on types of diseases (infectious, rheumatic, cancerous, mental, etc.). Today, specialties overlap: surgeons specialise in one part of the body or one type of surgery; paediatricians specialise in specific children's diseases, thereby expanding the number of fields in which to exercise medicine.

Also, these many competences are today performed very differently, doctors frequently combining one (or several) waged position(s) with private practice, alternating between the public and the private sectors. The medicine that thirty years ago was above all "general and liberal" seems to have disappeared. Yet, despite their diversity, all these ways of practising medicine do have a common object, which we have defined as curing (HARDY, 2013), understood here first and foremost as a process guiding medical activity in its diverse dimensions. That common work-object takes on different shapes and forms depending on the specialty that transforms it, and this may be best observed through the practical training specialists receive.

The second part of a doctor's undergraduate training is done "while employed", i.e. as a resident. According to the specialty chosen, a residency lasts between three years (for general medicine) and five years (surgical specialties) and can be extended if a Degree of Complementary Special studies (diplôme d'études spéciales complémentaires - DESC) and/or post-residency is embarked upon. Practising medicine in the field means practising a specialty learnt mainly in a hospital; therefore, where the resident works may differ quite considerably from where he/she will exercise professionally, if he/she subsequently works independently or in a private clinic. Behind the apparent uniformity of training procedures, strong variations subsist due to the 
disparity between learning and practising, theorising and doing, engaging in a specialty and defining the discipline. It is therefore difficult to paint a simple portrait of the learning process involved in such a multifaceted object, which is why we have chosen to broach it in a comparative and dynamic perspective. We will tackle training for a specialty in two fields by analysing their main, distinctive characteristic and where it originated. For example, general medicine was initiated as a specialty not on the basis of practice, but on the basis of training; this in itself created a paradox responsible for the fact that this professional segment had the greatest difficulties in becoming an academic discipline. Obstetrics, an ancient discipline but whose contours are porous, espoused the medicalisation of childbirth, based on the principle of the inherent risk, in order to build a new and original object.

\section{Forming Special Objects, General Medicine: from Training to Specialisation}

\section{A Formal Specialisation}

The shift towards medical specialisation -which culminated when general medicine was ousted as the profession's main reference, to the exclusive benefit of "medical specialties"- can be observed through the evolutions of the training system and modes of learning (for more information on the numbers of GPs, see Box 2). Specialisation was in fact concretely introduced into the French training system in three ways: through the system of selection, through its theoretical contents and through the organisation of internships. Training in view of a specialty is not the same as training to be a practitioner of primarily general medicine; the model changes.

In reality, general medicine was the last specialty for which selection was done according to rank. Before 1983, several models for choosing a medical practice existed, each reflecting a different value system. Hospital residents were considered the elite, selected in two ways: first because they succeeded in reputedly very difficult competitions but also because, once appointed, their superiors chose them as their disciples in the specialty. The residency competition (internat) gave access to hospital positions but was not a specialty competition; residents chose their specialty later. Doctors who did not want to be residents but wished to specialise could sit a certificate of special studies (certificat d'études spéciales-CES), but it only gave access to medical specialties. The hierarchy established by this system of selection is what gave surgery its reputation for excellence; surgical specialties were accessible only through residency, surgeons being very attached to the quality of practical training which they willingly referred to as a "compagnonnage" (Bercot, MATthiEU-Fritz, 2007; Zolesio, 2012; BERCOT, 2015). Traditionally, two sorts of training were therefore opposed, a throwback to the 
ancient doctor/surgeon conflict: one being intellectual, full of abstract knowledge, the other, practical, taught in the field and in the hospitals. ${ }^{12}$

In 1983, every specialty could be accessed through a residency, except for general medicine. This change had two consequences: from then on, accessing a specialty was dependent on the candidate's ranking, but all doctors received their training in a residency. From 1983 to 2004, general medicine was in a curious situation: not yet recognised as a specialty, but no longer truly common to all. Since it was not part of the residency system, it became the inevitable "choice" for those who failed the resident competition or decided not to take it, and rapidly became known as the "last resort". Yet, the promoters of the 1983 reform had hoped to re-enhance general medical studies by instauring a true third cycle. The force of the selective process prevailed, however, and, even more than before, the discipline was chosen by the least successful students. ${ }^{13}$

\section{Box 2}

\section{General Practitioners}

Counting GPs is delicate because one must distinguish between those who hold a degree in general medicine and those who actually engage in it (BLOY, SCHWEYER, 2010). It is estimated that $c a .40 \%$ of those who hold a degree in general medicine exercise a medical activity other than that of "family doctor" (ONDPS, 2008).'

On 1 January 2013, of a total medical population of 218,296 practitioners in activity, 101,803 doctors were qualified in general medicine (SICARD, 2013a). They are very unevenly spread out across the country. Barely two-thirds work in private surgeries (62\%), the others work in the public hospitals (16\%) or in various private or voluntary medical centres. The age pyramid shows an abrupt decline especially among the youngest generations.

General medicine is today mainly female, which was not traditionally the case. In 2013 , e.g., $62 \%$ of GPs under 40 were women, while among GPs aged 55 or over, female doctors only amounted to $27 \%$.

In France, GPs' incomes are among the lowest among independent practitioners, particularly since only $11 \%$ of them are registered in sector 2 , i.e. authorised to charge a

1. Observatoire national de la démographie des professions de santé (National Observatory of Health Professions Demography).

\footnotetext{
12. The evolutions of medical science have an impact on the way a profession's prestige evolves. Surgeons earned their stripes largely because aenesthetics and antibiotics allowed them to operate more easily and to limit the iatrogenic effects of their acts. Consequently, the results obtained by surgeons were more and more spectacular, until medical science discovered new therapeutic methods and new families of medication. Cardiology, for instance, became the king of medical specialties in students' desiderata, because it condenses all the positive sides of what they are looking for: a succinct body of knowledge easy to master, particularly spectacular results, acts that are both technical and clinical, a very comfortable financial return and an extremely valuable symbol, given the organ involved.

13. Evaluating "performance" here is purely academic: in fact, it concerns students who obtained the lowest grades on the university examinations.
} 
fee higher than the official Social Security rate (Bellamy, Mikol, 2012). For the young generations, that opportunity is practically non-existent: today, one must have done a post-residency to have the right to charge those fees, and positions in general medicine are extremely few and far between.

\section{DIAGRAM - General Medicine on 1 January 2013}

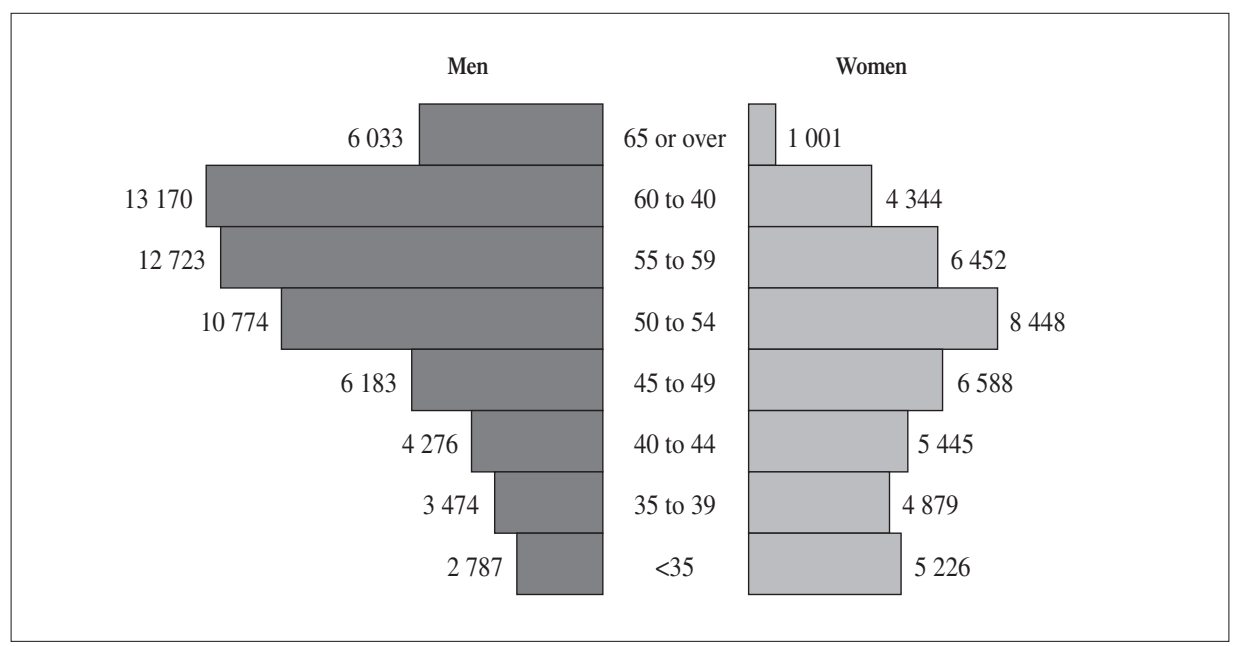

Source: Asip Santé (Agence des systèmes d'information partagés de santé), RPPS (Répertoire partagé des professionnels de santé), statistical treatments conducted by the DREES (SICARD, 2013a).

As of 2004, established as a "specialty", general medicine could be chosen like the others, i.e. following the ECN rankings. Since then, it has been gaining with regard to the other specialties: fewer students choose it only as a last resort, even if it is still true that those in the lowest rankings often have little choice aside from general medicine (GODEFROY, 2013).

At the same time, the theoretical contents of the first two cycles were modified. Until 2004, there were two ways to learn: either by studying at university, or by preparing the competitive residents' examination. At university, the aim was that all students should learn the same medicine, whereas preparing the competition was directed at specialised knowledge, the aim being to select the future residents. But little by little, in order to improve their performance at the competition, university departments readjusted their programmes and teaching styles to suit the competition, so that by 2004 , only one programme remained, in fact oriented towards specialised knowledge. Theoretical learning itself was transformed, prioritising segmented knowledge, concentrating on specialised pathologies to the detriment of the transversal knowledge that universities used to dispense. During interim periods, it was noted that, depending on the university department, and depending on whether the aim was to form mainly specialists or generalists, the subjects taught differed considerably. 
From the point of view of practical training, things became more complex. For if the aim is to give students practical experience, what field is best suited for general medicine? Realistically, training doctors to exercise a liberal sort of medicine in a private office, it would be best for them to intern with a GP in town. However, the very principle of private practice is poorly suited to hosting a trainee. It was therefore necessary to set up a mixed system whereby GPs became internship masters, capable of welcoming a trainee but without guaranteeing any sort of uniform training or even any sort of easily controllable pedagogical quality (BLOY, 2005). The gap between training in a hospital and training in a private surgery, aggravated by hospital professors who promoted the model of specialised expertise while denigrating general urban medical practice, made fledgling GPs, uneasy and uncomfortable with liberal practice, turn to other ways of exercising the trade.

General medicine therefore became specialised in its form rather than in its object, since the discipline does not really correspond to any practical or technical innovation that would radically alter the division of labour in the field. That is the reason why students and teachers seek to redefine their object after the fact, so as to distinguish it from other specialised objects, but on a practical basis this time.

\section{An Anomic Specialty?}

How then does the work-object of general medicine take shape? Part of the reason the issue is confused is that training was set up on the model of specialised medicine. In fact, general medicine became a specialty not as a result of having redefined its object but because it was submitted to the same systems of selection and training as the medical specialties. Paradoxically, this both reduced its scope -it no longer concerned all doctors- and reinforced it: on the new horizon, exclusively peopled by specialists, it became numerically the most important specialty. At the same time, its implementation was not thought out afresh and, though practices evolved, the activity was not fundamentally restructured by the specialty. The main challenge for "specialised" general medicine today is developing an object that can be recognised and acknowledged in the same way as in the other specialties.

Given these difficulties, research in general medicine has concentrated on defining its object more than on fleshing it out. What emerges is a model for approaching it, called biopsychosociology (ENGEL, 1980), in which authorities of disciplines other than those of the traditional medical sciences are summoned. The point is to propose both a "global approach" of the patient and to be seen as legitimate by espousing the model of Evidence Based Medicine (EBM). ${ }^{14}$ The other specialties materialized by breaking away from general medicine, referring to a specific population, a technique

14. Evidence Based Medicine tends to modify the paradigm of clinical thinking that formerly rested mainly on the clinician's experience, replacing it by a decisional paradigm based on scientific proof and accessible in the scientific literature and meta-analyses. EBM is part of a vaster set of statistics used as proof, developed in the 20th century in medicine as well as in public policy or economic arbitration (DESROSIÈRES, 2008). 
or a body part. General medicine cannot be differentiated in the same way, because it is trapped in its attempts to improve its own standing. Its strategy is to set itself apart from all the other specialties thanks to an original approach, referring more to a process, a modus operandi, than to an object per se. In a training system based on specialised knowledge, the so-called "global" approach of general medicine corresponds to a particular professional socialisation. As some have pointed out, they must learn "in reverse", since it means starting from the patient to discover the disease. Therefore, during the third cycle of medical studies, university professors pay greater attention to the way decisions are made, to listening to the symptoms, to the patient's environment, to social inequalities, etc. -factors that are no longer present in the general medical syllabus or only in standardised forms, such as the Social and Human Sciences (SHS), whose status remains hazy, or ethics, sometimes relegated to being simply optional.

That paradoxical situation puts general medicine in a position bordering on anomie, in the sense suggested by DuRKHEIM (1981 [1930, 1st ed.]): it is not the lack of participating in a collectivity that is at stake here, but the coherence of the fundamental values that permit a group to rally round a common object. At best, GPs could rally round a societal mandate represented by the role of gate-keeper played by the "primary care physician". But medical science is not part of the definition and, for students whose entire education focused on specialisation, identifying with a role of gate-keeper -not a particularly prized position in the French system- would doubtless be problematic.

\section{Forming Special objects, Obstetrics: Forming a Risky Object}

Obstetrics is a specialty that is not organised round a disease, but rather round an event: childbirth (for details on the numbers of obstetrician-gynaecologists, see Box 3).

\section{Box 3}

\section{Obstetrician-Gynaecologists}

As of 1 January 2013, there were 5,935 obstetrician-gynaecologists, more or less evenly divided among state hospitals $(2,377)$ and the private sector, i.e. in private surgeries $(2,289)$ and establishments. It is one of the medical populations whose numbers have least plummetted. That remark must nevertheless be tempered by the near-disappearance of medical gynaecology since the 1980s.

The profession counts an average of $41.9 \%$ women, and feminisation increases considerably as one moves into the youngest age-groups. This shift is all the more remarkable as it is a surgical sector, still a discipline in which women are relatively few in number (BERCOT, 2015; ZOLESIO, 2015).

$\mathrm{G} \& \mathrm{O}$ incomes are fairly high. But it is difficult to obtain a true evaluation, for part of them -the obstetricians- are usually counted with the surgeons. It should also be noted 
that G\&O careers may differ, in that many of them drop obstetrics at a certain point to give themselves completely to gynaecology, whether surgical or only medical.

\section{DIAGRAM - G\&O on 1 January 2013}

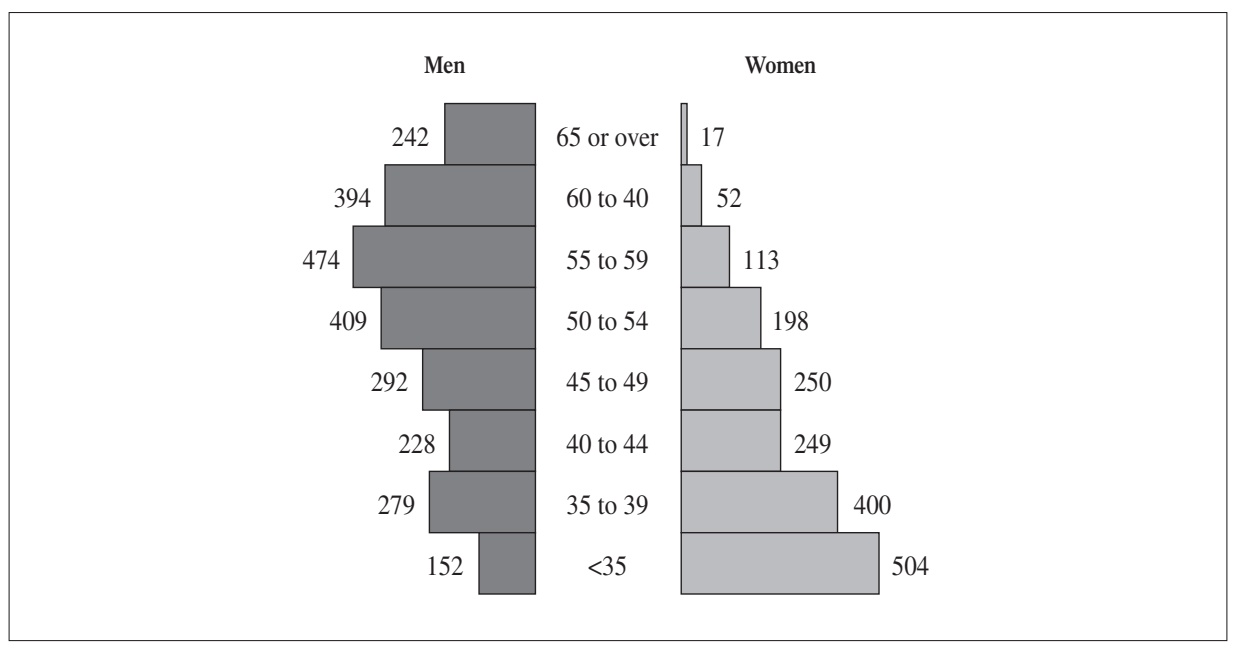

Source: Asip-Santé RPPS, statistical treatments conducted by the DREES (SICARD, 2013a).

However, though medicalised, childbirth is not a medical event: it takes place outside medicine - not the case of cancerology, a disease that requires a specific approach-and outside the healthcare system, that created the general practitioner. What then is the reference that allows the doctor to interfere during a delivery and in what way is that object specific from the standpoint, for instance, of a midwife?

The theoretical and "official" answer to that question is the distinction between a "normal" (eutocic) and a pathological delivery (JACQUES, 2007). In other words, what differentiates the two is precisely the doctor's intervention, since a midwife takes care of deliveries that do not require the medical act that doctors are supposed to perform at a given moment (applying forceps, for instance). The boundaries between those different competences are quite unstable, and in the end, it is the notion of risk, itself not very well defined, that contributes to drawing them.

\section{A Branch with Shifting Boundaries}

$\mathrm{O} \& \mathrm{G}$ is a branch attached to the surgical disciplines. But it is particular in that it is positioned at the boundary of several practical fields. ${ }^{15}$ First of all, it includes both

15. Aside from experimental or non-prescriptive specialties (such as occupational medicine), the field is divided into medical and surgical specialties. In fact, surgery was first a specialty in itself (general surgery), as opposed to medicine. Then the move towards specialisation generated, within those two modes of practice a division, or even 
gynaecology and obstetrics. The specialty is centred on a population (women), on organs (female genitals) and on a specific time (maternity). It is also at once medical and surgical, concerned with non-pathological, physiological phenomena (such as contraception or childbirth). That puts it in competition with other medical specialties, such as general medicine or endocrinology (the study of hormones) as well as other professions, in particular midwifery (an allegedly medical profession but separated from the medical body to which they are institutionally subordinated).

France is one of the few European countries that developed, after the Second World War, a medical specialty known as gynaecology, distinct from surgery and obstetrics. ${ }^{16}$ That area of training was eliminated in 1983 , replaced by O\&G, included among the surgical branches. Though today medical gynaecology has reappeared thanks to a few in residence posts, it remains very marginal and is insufficient for renewing the population of such specialists. ${ }^{17}$ The hard fact is that women's gynaecological followup can today be done by GPs - of whom several have also acquired qualifications in the field-as well as, more recently, by midwives. ${ }^{18}$ The same are also entitled to follow up so-called non-pathological pregnancies. In the public sector and some private clinics, delivery is taken in charge by midwives, there again in non-pathological situations. Only technical acts and operations (gynaecological surgery and caesarians) are carried out exclusively by obstetrician-gynaecologists.

While obstetrics seem to be clearly defined by the responsibility attached to specific acts, the discipline is in fact essentially defined by a notion difficult to pin down: pathology. Far from imagining the passage from "normal" to "pathological" as a continuum whose borders are constantly being socially as well as scientifically redrawn, as Georges CANGUILHEM (1966) leads us to think, the way specialties are organised gives the impression a rupture has occurred, also implied by the change of persons officiating and by a change in the rules. Historically, too, O\&G was introduced into the French hospital system during an ongoing war between men (doctors) and women (midwives and matrons) to monopolise not only a practice but also a specific know-how. ${ }^{19}$ Inciting women to give birth in hospital during the 19th century can hardly be justified by the argument of better security, since women frequently died from

\footnotetext{
sometimes a pairing of specialties. For example, dermatology and otorhinolaryngology (ear, nose and throat) are both medical and surgical, and training for those specialties applies the patterns of training in surgery. G\&O is one of those mixed specialties and those who choose it can also do medical gynaecology; some doctors nearing retirement choose precisely that, e.g. in order to avoid being on call.

16. This is specifically due to feminist activists lobbying for hormonal vs. surgical treatments in cases of gynaecological pathologies (WEISZ, LöWY, 2005).

17. The average age of medical gynaecologists is 59 and, of a total population of 3,600 specialists actually in activity, there are only 129 gynaecologists aged under 45 (SICARD, 2013a, p. 98 et seq.).

18. There are presently over 20,000 midwives in France, of whom approximately $20 \%$ work in the private sector (SICARD, 2013b). They are classified as a "medical profession", but the definition is ambiguous because, though they have the right to decide and to prescribe, it is only in so-called "physiological" (non-pathological) situations.

19. Matrons being women and frequently also mothers of large families, assisted women in childbirth in the absence of health professionals. Midwives and matrons competed throughout the 19th century for home deliveries; since the very beginning and even in hospitals, midwives have proved quite capable of defending themselves (FAURE, 2005).
} 
the puerperal fevers linked to infections known today as nosocomial. Hospitalisation in the 19th century can often be explained by doctors' need to carry out deliveries independently from the midwives in order to improve their techniques and build up their own body of knowledge (Schlumbohm, 2002).

\section{Curing a Risk}

Describing Dr. Osiander's activities in the maternity ward of Göttingen University at the start of the 19th century, Jürgen Schlumbohm (2002) shows that at the time practitioners did not hesitate to resort to instrumental extractions during delivery without real need, for the sole purpose of teaching their students or carrying out a technical demonstration. From the very beginning, the science of obstetrics therefore is like a technique that allows doctors to control the course of an ongoing delivery and impose their own norms. The specialty figured as an autonomous discipline attached to surgery, to direct intervention therefore, rather than as a branch of maieutics, defining the science and techniques of birth. The distinction is crucial: it fundamentally cut obstetricians off from midwives and the fact the conflict regularly resurfaces is not innocuous.

Observing labour in the delivery-room ${ }^{20}$ yields a better understanding of the way the work-object materializes for each category of personnel, midwives and obstetriciangynaecologists in particular.

Aside from medical taxinomies, we became aware of three types of delivery, depending on how functions are distributed among doctors and midwives. The first type may be called "spontaneous" or "natural" -even if no child is born in a large hospital without some sort of technical and professional intervention. Deliveries requiring a minimum of medical intervention and totally managed by midwives may however be included in this category. The second type of delivery can be qualified as "directed", to use their own expression. In that case, the action of health professionals consists in taking the course of labour "in hand", i.e. attempting to master the different phases -often to speed it up- but without resorting to directly interventionist techniques. In general, the midwives decide to "direct" a delivery, but they inform the doctors and stay in touch with them in case an intervention is necessary. Lastly, there are the deliveries I have named "constrained", in the sense that a doctor modifies the course of delivery,

\footnotetext{
20. The "delivery room" is the ward where women give birth. It is the term midwives prefer, while doctors call it the "obstetrics block", which underlines a not so innocent difference. The signposts in hospitals have adopted the doctors' vocabulary. What is more, that "block" is adjacent to the "gynaecological block" where gynaecological operations take place. But it also shares similarities with the emergency wards, because activities are not planned ahead of time: in the first place, they depend on the arrival of parturient women and, secondly, the personnel is organised on a 24 hour-a-day, seven-days-a week basis, like guard duty. We carried out a series of observations in the delivery room of a public hospital over a period of seven months, in 2012-2013. We followed various members of personnel on their guard duty, concentrating particularly on the professionals' work, the ways they cooperated (or didn't), their limits and complementarities, seeking to explore the key question: is it possible to define a common object for health professionals working in a delivery-room, or does each embrace a separate object?
} 
at whatever stage the labour happens to be in. Concretely, such interventions can take quite different forms: manipulating the fotus in utero, instrumental extraction, or even a Caesarean. Whatever the case, something takes place that "alters" the course of the delivery, or at the very least attempts to do so-for medical acts are sometimes thwarted and "spontaneity" may win out in the end.

Just as doctors intervene at a very particular moment during certain deliveries, upsetting the course of events, residents too are above all trained to get moving at those moments. The act itself testifies to a real break between, on the one hand, the idea of delivery as a process leading to the birth of a child, and, on the other, its medicalisation, consisting in "taking it in hand", i.e. acting "against" the natural process, just as one acts "against" a disease. That rupture is also contained in the term used to talk about the doctor's patient: not the parents" "child" but the "fetus". Different from its future as baby and described only as a series of disembodied medical problems (LEWIN, 2004), ${ }^{21}$ the fetus represents both the whole and its parts (the "mobile fetus", the "fetal head", etc.).

Residents' training, which includes some specific features, spectacularly reveals the ruptures leading to the emergence of the obstetrical work-object.

First of all, they learn to "do things" basing themselves on precise techniques. For example, one resident I spoke to explained that one of the first things she had learnt to do during her residency was a Caesarean, though she had never yet done a physiological delivery. Residents thus learn how to "do" before learning to "prescribe": they are taught to handle forceps before learning the right time to use them. Doing so, they develop a vision of their act independently from what preceded it, as if it was the most important part of the process.

Secondly, they learn the method for making a decision: one must spot the "risks", assess them and eventually act accordingly. This is done during staffs, ${ }^{22}$ when situations are presented and discussed with senior physicians or, more formally, during a class based on case studies. They also learn to consult the "procedures" and "good practices" to know what they have the "right" to do. They employ a frequently legalistic vocabulary: is it "prohibited", do you "have the right", is it "mandatory", etc.?

Lastly, and almost as simply an adjunct to their education, they go to "see" how things happen "spontaneously". In that case, they do little or nothing, for in a large hospital, the apprentice midwives do not readily allow them to take their place. This sometimes makes them think that a physiological delivery is a "non-event", that they must only know about much as one learns the ropes in a professional environment.

21. For instance, the "transfer of the in utero fetus" means a pregnant woman has been transferred to a different hospital. 22. Staff is the term used in hospitals to describe meetings of medical teams in view of decision making. These are different from department meetings, sometimes attended by all the professionals -medical and paramedical- of a care unit. 
In the end, the process of learning the medical task of delivery clearly differs from the one midwives follow traditionally. In fact, student midwives ${ }^{23}$ learn to carry out the most technical acts towards the end of their training, first learning the physiology of childbirth and its many manifestations. What is "normal" is never quite the same and it is precisely the multifaceted aspect of spontaneous occurrences that constitutes their specialty. In contrast, doctors learn the expert act: their object is to proceed with the delivery as they see it and to apply the technique successfully, even if it means going counter to the normal evolution of a woman's labour.

What stands in for the disease in this case is not the birth or the delivery, but "the risk". However, the concept of risk must be understood here not as a hypothesis or a probability, but as the actual emergence of a disorder that triggers action. Risk is evil. That very particular conception is at the root of the phrase most often heard in the delivery rooms and obstetrics classrooms: "You know there was no risk involved when the delivery is over and nothing went wrong." What is at stake when overseeing a pregnancy, for instance, is eliminating risks, based on the idea that they cannot all be eliminated and keeping in mind that danger is always just round the corner. Consequently, the concept of "normal pregnancy" has disappeared in France, ${ }^{24}$ leaving only pregnancies with a low, average or high risk-factor, and a classification of maternity wards according to their capacity for risk management, assessed by the equipment available to care for the new-born.

Analysing how the medical object is formed -from an institutional as well as a practical point of view-permits complexifying an often overly-homogenised vision of the medical profession. The central and common object is indeed learning a procedure -curing- but by taking off from the object "disease", reconstructed in such a way that the doctor can grasp or even master it, which in a sense leaves the sick person's body behind. Curing, here, is understood as fighting against the disease, not that the patient has recovered. Whatever the patient may be feeling, the healing process is only made possible by being linked to an identified disease. That is why it is necessary for that disease to be expressed by a risk that allows the doctor to intervene during the pregnancy -pathology notwithstanding and even, more generally, when deciding what preventive measures to apply.

Thus, practical training is not what makes a doctor's job concrete. Though the facts and the acts are tangible, its object is not necessarily so, which casts light on a certain number of frequently observed phenomena. Among the latter, one might mention the forewarnings concerning general medicine (BLOY, 2011): it no longer seems attractive for young doctors, and the result has been the advent of "medical deserts". The press

23. Over $95 \%$ of midwives are women.

24. This is not the case in all Western countries, as research by Madeleine AKRICH and Bernike PASVEER (1996) on childbirth in France and the Netherlands has demonstrated. 
regularly highlights students' falling out of love with the job, and professionals report that practitioners are not comfortable with it. Research also seems to be revealing serious signs of burnout among GPs, even of frequent suicides, also linked to the fact that young doctors put off opening their own office, in contexts where they are not necessarily under less pressure than their seniors. ${ }^{25}$ Though one must take the results of the medical profession's soul-searching -which tends to be readily pessimistic- ${ }^{26}$ with a grain of salt, it is also necessary to take such expressions of dismay -also imparted by the most convinced professionals, i.e. the teachers-into account.

One may well wonder what the connection might be between these signs of malaise and the loss of a work-object by half-numerically-of the medical profession. It shows that a discipline and, even more so, a practical specialty, cannot be launched without being attentive to the coherence of the fundamental, underlying work-object. GPs are the ones who, when finding themselves obliged to take a patient's complaints into account, expressed the idea they had to "learn all over again, but in reverse". How can one reconcile the biomedical approach, on which research in a university hospital is based, and the consulting physician's?

The questions raised by $\mathrm{G} \& \mathrm{O}$ are different but complementary. The way obstetricians learn their job is not directly related to the birth event, but follows the logics of a power-struggle to dominate the parturient woman's labour by taking the "fetal object" in hand, at a given moment. In France, the conflict that arises between midwives and obstetricians when the first demand to be recognised as a "medical profession" then becomes easily comprehensible. Since the medical object was built up in opposition to physiology, acknowledging that the professionals in charge of that physiology are medically qualified would mean disqualifying their object, or even discarding its distinctive substance.

Finally, these results emphasise the difference between training "in the field" and "while employed". Previous generations of doctors were trained "while employed" -thrown into the fray and left largely to their own devices- which was probably detrimental to their patients. They often chose a specialty after having practised it for a while; they tried out general medicine before deciding to stay with it or not (HERZLICH et al., 1993) and could also change directions or ways of doing things over the course of their career. Practical internships today do not fill exactly the same function: they come after a period of theoretical apprenticeship, and espouse a translational process ${ }^{27}$.

\footnotetext{
25. On the extreme complexity and the very strong pressure placed on the GPs of previous generations, see the remarkable book by John BERGER and Jean MoHR (2009), charting the work of a GP in the English countryside in the 1960 s.

26. Research carried out on panels of GPs do show very different situations of stress at work which are not necessarily worse than for all workers, particularly in the other higher categories (ORS, URML, 2010).

27. Translational research aims to study the implementation of research results obtained in laboratories and tested at best on animals. It is an important aspect of biomedical research today, often problematic due to the difficulties in cooperating and the differences in approach between researchers and clinicians.
} 
It would nevertheless be inexact to say that the medical work-object has been "formed" once and for all when leaving medical school. It is bound to be modified throughout one's career, most often outside a university hospital structure. Though the list is incomplete, several avenues of research deserve to be mentioned here, which may contribute to elucidating how, beyond medical curricula, the medical object is mobile and constantly changing. The first bears on working conditions outside hospital contexts. Both of the specialties we examined here encounter different hazards in the private and liberal sector. GPs, for example, are faced with patients whose demands vary as time marches on, on the one hand, and with ever more stringent modes of control on the part of the responsible authorities, on the other hand. It is noteworthy that having introduced pay-for-performance or new forms of primary care organisation participate in changing the object as well as the ways one relates to it. Is defining collective objectives or care-giving liable to "deform" the medical work-object?

Though we distinguished the formal positions of midwives and doctors confronted by different types of delivery in hospital contexts, the distinction is only applicable in the very specific context of a French university-hospital. In a private clinic for example, including Level 1 clinics, ${ }^{28}$ where most deliveries take place at no great risk, doctors intervene at the moment of birth without modifying the course of eutocytic labour. Their intervention is often a financial issue, since every medical act implies a remuneration. Pay-by-performance or by-the-act poses that sort of problem in a hospital too. An act's "value" is not only symbolic or medical; in our system, it is also determined by its profitability.

Scientific evolutions and new ways of considering diseases must also be taken into account. The ever-larger place occupied by predictive medicine leads scientists, clinicians included, to seek other ways of caring for the patient. Since a disease is put down to a genetic heritage or to biological markers, the more-or-less automatic diagnosis of those predispositions might, in some cases, dictate the medical prescription. Besides, attributing a mission of technological and cutting-edge research to public hospitals causes the resolution of everyday problems to be transferred to the mainly private, ambulatory system. Does this not run the risk of restricting medical work to the implementation of an object created further and further away from the patients and what they actually experience?

In conclusion, our results also incite us to interrogate the model of medical training in comparison with the other health professions, particularly the articulation between theory and practice in some of them. Curtailing nurses' training was an opportunity to rebuild the curriculum, giving precedence to theoretical knowledge at the start of their studies, to practical application at the end. The same goes for midwives, who do fewer internships at the beginning of their training. Though several medical options are available during the first year of medical school, the disciplines in which they are made

28. Maternity wards are classified in three categories: levels $1,2 \& 3$ indicate (in descending order) the performance of neonatal reanimation units. Level 1 maternity wards thus correspond to those where delivery is judged to be the least at risk. 
to compete remain abstract. If in future medical university departments are required to include the main medical and paramedical professions, the risk is that the fusion take place the same way as it did for general medicine when it became a "specialty", i.e. by holding up the most prestigious branches as models to redesign the forms of the professions -but without reconsidering their object.

\section{REFERENCES:}

AKrich, M., PASVeER, B. (1996). Comment la naissance vient aux femmes. Les techniques de l'accouchement en France et aux Pays-Bas. Le Plessis-Robinson: Synthélabo.

ARLiaud, M. (1987). Les Médecins. Paris: La Découverte.

BASZANGER, I. (1981). « Socialisation professionnelle et contrôle social : le cas des étudiants en médecine futurs généralistes. » Revue française de sociologie, 22(2), 223-245.

Becker, H. S., Geer, B., Hughes, E. C., Strauss, A. L. (2005 [1961, 1st ed.]). Boys in White. Student Culture in Medical School. New York: Transaction Publishers.

Bellamy, V., Mikol, F. (2012). «Les revenus d'activité des médecins libéraux : le poids des dépassements ». Études et résultats, 811. Paris: Direction de la recherche, des études, de l'évaluation et des statistiques (Drees).

Bercot, R., MATHIEU-Fritz, A. (2007). « La crise de recrutement des chirurgiens français : entre mythes et réalités. » Revue française de sociologie, 48(4), 751-779.

BERCot, R. (2015). « Le devenir des femmes en chirurgie: la diversité des mondes de socialisation. » Travail et Emploi, 141, 37-52.

BERgER, J., MoHr, J. (2009). Un métier idéal : histoire d'un médecin de campagne. Paris: Éd. de l'Olivier.

BIDET, A. (2010). « Qu'est-ce que le vrai boulot? Le cas d'un groupe de techniciens. » Sociétés contemporaines, 78, 115-135.

Billaut, A. (2006). «Les cessations d'activité des médecins. » Études et résultats, 484. Paris: Drees.

BLOY, G. (2005). « La transmission des savoirs professionnels en médecine générale : le cas du stage chez le praticien. » Revue française des affaires sociales, 1, 101-125.

BLoY, G. (2011). « Comment peut-on devenir médecin généraliste aujourd'hui ? Le renouvellement des médecins généralistes vu à travers une cohorte de jeunes diplômés. » Revue française des affaires sociales, 2-3, 9-28.

Bloy, G., SchweYer, F.-X. (ed.) (2010). Singuliers généralistes. Sociologie de la médecine générale. Rennes: Presses de l'École des hautes études en santé publique.

Bourdieu, P., Boltanski, L. (1975). « Le titre et le poste : rapports entre le système de production et le système de reproduction. » Actes de la recherche en sciences sociales, 1(2), 95-107. 
Boussard, V., Demazière, D. \& Milburn, P. (2010). L'Injonction au professionnalisme. Analyses d'une dynamique plurielle. Rennes: Presses universitaires de Rennes.

Calmand, J. (2013). « Les docteurs : une longue marche vers l'emploi stable. » Bref du Céreq, 316.

Canguilhem, G. (1966). Le Normal et le Pathologique. Paris: Presses universitaires de France.

Chapoulie, J.-M. (1973). « Sur l'analyse sociologique des groupes professionnels. » Revue française de sociologie, 14(1), 86-114.

Cicourel, A.-V. (2002). Le Raisonnement médical. Une approche sociocognitive. Textes réunis et présentés par P. Bourdieu et Y. Winkin. Paris: Seuil.

Demazière, D. (2008). «L'ancien, l'établi, l'émergent et le nouveau : quelle dynamique des activités professionnelles ? » Formation emploi, 101, 41-53.

Demazière, D. (2009). « Posface. Professionnalisations problématiques et problématiques de la professionnalisation. » Formation emploi, 108, 83-90.

Demazière, D., GadÉA, C. (Eds.) (2009), Sociologie des groupes professionnels : acquis récents et nouveaux défis. Paris: La Découverte.

Desrosières, A. (2008). L'Argument statistique. Vol. 1 : Pour une sociologie historique de la quantification. Paris: Mines ParisTech.

Dodier, N. (1993). L'Expertise médicale. Essai de sociologie sur l'exercice du jugement. Paris: Métailié.

Dubas, F. (2004). La Médecine et la question du sujet. Enjeux éthiques et économiques. Paris: Les Belles Lettres.

DuRKhEIM, É. (1981 [1930, 1st ed.]). Le Suicide : étude de sociologie. Paris: Presses universitaires de France.

Engel, G. (1980). “The Clinical Application of the Biopsychosocial Model.” American Journal of Psychiatry, 135, 535-544.

FAURE, O. (2005). « Les sages-femmes en France au XIX siècle : médiatrices de la nouveauté. » In P. Bourdelais, O. Faure (Eds.), Les Nouvelles Pratiques de santé, XVIII -XX ${ }^{e}$ siècles (pp. 157174). Paris: Belin.

Foucault, M. (1963). Naissance de la clinique : une archéologie du regard médical. Paris: Presses universitaires de France.

Freidson, E. (1970). La Profession médicale. Paris: Payot.

Friedmann, G. (1950). Où va le travail humain ? Paris: Payot.

GadéA, C., Hardy-Dubernet, A.-C. (Eds.) (2005). «De "faire médecine" à "faire de la médecine”. » Document de travail, Série Études, no 53, Paris: Drees.

Godefroy, P. (2013). «Les affectations des étudiants en médecine à l'issue des épreuves classantes nationales en 2012. » Études et résultats, 852. Paris: Drees. 
HaRdy, A.-C. (2013). Travailler à guérir. Sociologie de l'objet du travail médical. Rennes: Presses de l'École des hautes études en santé publique.

Hardy-Dubernet, A.-C., Faure Y. (2006). « Le choix d'une vie... Étude sociologique des choix des étudiants de médecine à l'issue de l'examen classant national en 2005. » Document de travail, Série Études, no 66, Paris: Drees.

Herzlich, C., Bungener, M., Paicheler, G., Roussin, P. \& Zuber, M.-C. (1993). Cinquante ans d'exercice de la médecine en France. Carrières et pratiques des médecins français 19301980. Paris: éditions Inserm/Doin.

Hughes, E. C. (1996). Le Regard sociologique : essais choisis. Textes rassemblés et présentés par J.-M. Chapoulie. Paris: École des hautes études en sciences sociales.

JACQUES, B. (2007). Sociologie de l'accouchement. Paris: Presses universitaires de France.

Jamous, H. (1969). Sociologie de la décision. La réforme des études médicales et des structures hospitalières. Paris: Éditions du CNRS.

LABArthe, G., Hérault, D. (2003). « Les étudiants inscrits en médecine en janvier 2002. » Études et résultats, 244. Paris: Drees.

LEwIN, F. (2004). «L'obstétricien, les parents et le fœtus malade. » In S. Séguret, Le Consentement éclairé en périnatalité et en pédiatrie (pp. 79-82). Paris: Eres.

ONDPS (2008). Rapport annuel 2006-2007 de l'Observatoire national de la démographie des professions de santé, Tome 1 : La médecine générale. Paris: Ministère de la Santé, de la Jeunesse, des Sports et de la Vie associative.

Observatoire RÉgional de la santé des Pays de la Loire (ORS), Union RÉGionale des MÉDECINS LIBÉRAUX DES PAYS DE LA LOIRE (URML) (2010). Vie professionnelle, vécu du travail et état de santé des médecins généralistes des Pays de la Loire, vague d'enquête 4 - 2008. Rapport détaillé. Online http://www.santepaysdelaloire.com/ors/sites/ors/files/publications/ PanelMG/2010panel1_v4_rapport.pdf (accessed 23 October 2017).

PENEFF, J. (1997). « Le travail du chirurgien : opérations à cœur ouvert. » Sociologie du travail, 39(3), 265-296.

Pinell, P. (2004). « Champ médical et processus de spécialisation. » Actes de la recherche en sciences sociales, 156-157, 4-36.

Piotet, F. (2002). La Révolution des métiers. Paris: Presses universitaires de France.

Schlumbohm, J. (2002). « Comment l'obstétrique est devenue une science. La maternité de l'université de Göttingen, 1751-1830. » Actes de la recherche en sciences sociales, 143, 18-30.

SiCARD, D. (2013a). «Les médecins au $1^{\text {er }}$ janvier 2013. » Document de travail, Série Statistiques, no 179, Paris: Drees.

SiCARD, D. (2013b). «Les professions de santé au $1^{\text {er }}$ janvier 2013. » Document de travail, Série Statistiques, no 183, Paris: Drees.

Strauss, A. (1992). La Trame de la négociation. Sociologie qualitative et interactionniste. Textes réunis et présentés par I. Baszanger, publiés entre 1961 et 1985. Paris: L'Harmattan. 
WeIsz, G. (2006). Divide and Conquer. A Comparative History of Medical Specialization. New York, Oxford: Oxford University Press.

Weisz, G., Löwy, L. (2005). "French Hormones: Progestins and Therapeutic Variation in France." Social science and medicine, 60, 2609-2622.

Zolesio, E. (2012). Chirurgiens au féminin? Des femmes dans un métier d'hommes. Rennes: Presses universitaires de Rennes.

Zolesio, E. (2015). « Des modalités d'apprentissage brutes et brutales en chirugie. » Travail et Emploi, 141, 25-35. 